\title{
MANAJEMEN KEPALA SEKOLAH DALAM PENINGKATAN PROFESIONALITAS GURU PENDIDIKAN AGAMA ISLAM MAN 3 SLEMAN YOGYAKARTA
}

\author{
Indel \\ Universitas Islam Negeri Sunan Kalijaga Yogyakarta \\ e-mail: indeluinsuka@gmail.com
}

Diterima: 29 April 2020 | Direvisi: 14 Mei 2020 | Disetujui: 25 Mei 2020

(C) 2018 Program Studi Pendidikan Agama Islam Fakultas Agama Islam Universitas Islam Malang

\begin{abstract}
In the context of regional autonomy and decentralization of education the succeed also failure of education in schools is techer as educator, principals, and supervisors, because these figures are the keys that determine and mobilize various other school components and dimensions. To achieve the expected goals, it takes an organization in which there is organization cooperationor ganizational cooperation. This research is included in the field research namely: this research is carried out in a certain environment to carry out observations and data collection needed. The research was conducted by researchers at MAN 3 Sleman Yogyakarta, this research method uses descriptive qualitative research. In terms of its nature, this research is descriptive in nature, that is, research that aims to systematically and accurately describe the facts and characteristics of a particular field. The results of the study of the headmaster of the school have applied management in the improvement of the professionalism of PAI MAN 3 S teachers in Yogyakarta, this is evident that the teachers of MAN 3 Sleman have extensive mastery as evidenced by the standardization of certification. And have very personal competencies so that they can communicate very well with other staff.
\end{abstract}

Keywords: Management, Professionalism, Principal

\begin{abstract}
Abstrak
Dalam konteks otonomi daerah dan desentralisasi pendidikan, keberhasilan juga kegagalan pendidikan di sekolah adalah techer sebagai pendidik, kepala sekolah, dan pengawas, karena angka ini merupakan kunci yang menentukan dan memobilisasi berbagai komponen dan dimensi sekolah lainnya. Untuk mencapai tujuan yang diharapkan, dibutuhkan sebuah organisasi di mana ada organisasi kooperasiatau kerjasama ganizational. Penelitian ini termasuk dalam penelitian lapangan yaitu: penelitian ini dilakukan di lingkungan tertentu untuk melaksanakan pengamatan dan pengumpulan data yang diperlukan. Penelitian ini dilakukan oleh peneliti di MAN 3 Sleman Yogyakarta, metode penelitian ini menggunakan penelitian kualitatif deskriptif. Dalam hal sifatnya, penelitian ini adalah deskriptif di alam, yaitu, penelitian yang bertujuan untuk secara sistematis dan akurat menggambarkan fakta dan karakteristik dari bidang tertentu. Hasil kajian kepala sekolah telah menerapkan manajemen dalam peningkatan profesionalisme para guru PAI
\end{abstract}


MAN 3 S di Yogyakarta, hal ini terbukti bahwa para guru dari MAN 3 Sleman memiliki penguasaan luas yang dibuktikan dengan standardisasi sertifikasi. Dan memiliki kompetensi yang sangat pribadi sehingga mereka dapat berkomunikasi dengan baik dengan staf lain.

Kata Kunci: Manajemen, Profesionalisme, Kepala Sekolah

\section{Pendahuluan}

Dalam Undang-Undang Republik Indonesia Nomor 20 Tahun 2003 dalam pasal ayat 3 menyatakan bahwa tujuan dari pendidikan Nasional adalah untuk mengembangkan potensial peserta didik supaya menjadi manusia yang beriman, taat beribadah, bertaqwa kepada Tuhan Yang Maha Esa, berakhlak mulia dalam budi pekerti, sehat jasmani, berilmu pengetahuan yang luas, kecakapan dalam berbicara, kreatif, mandiri, dan menjadi warga yang demokratis serta bertanggung jawab terhadap apa yang dilakukannya. Sedangkan pada ayat 2 ditegaskan bahwa system pendidikan Nasional adalah pendidikan yang berawalkan pancasila dan UUD Negara Republik Indonesia Tahun 1945 yang berakar pada prinsip nilai-nilai keagamaan, kebudayaan Nasional Indonesia dan mampu mengikuti terhadap perubahan globalisasi dan perubahan zaman. sedangkan pada ayat 3 dikemukakan bahwa dalam sistem Pendidikan Nasional adalah keseluruhan komponen yang terlibat dalam pendidikan yang saling terkait secara terpadu demi mencapai tujuan pendidikan nasional (Kompri ; 2015).

Dalam konteks otonomi daerah dan desentralisasi proses pendidikan, bahwa keberhasilan atau kegagalan suatu pendidikan dilembaga sekolah, sangat tergantung pada, guru, kepala sekolah, pengawas, dan staf-staf lainnya, karena figur seseorang tenaga kependidikan merupakan kunci yang utama dan sangat berperan penting dan mempengaruhi dalam menentukan, mencapai serta menggerakan berbagai komponen dan, program-program dan dimensi sekolah yang lainya (Mulyasa ; 2012). Keadaan ini menjawab, bahwa baik buruknya komponen sekolah yang lain sangat ditentukan oleh SDM, kompetensi guru, peran manajemen kepala sekolah, serta para pengawas lainnya. tanpa mengurangi arti penting dari tenaga pendidikan yang lain. Peran penting kepala sekolah sebagai pemimpin untuk mencapai tujuan sekolah adalah mengatur, mengawas, merencanakan dan mengelola tiga hal pokok, yaitu manajemen personalia, manajemen sarana dan prasarana, manajemen kesiswaan, manajemen kurikulum dan manajemen keuangan. . Dengan kebijakanan ini, kepala sekolah dapat mengaplikasikan sistem bagi tugas, kepada para guru, staf- 
staf, dan para pengawas lainnya. artinya, kepala sekolah merencanakan, menggerakan, serta mengatur personalia yang terlibat dalam suatu lembaga tersebut, sehingga untuk mencapai suatu tujuan yang telah direncanakan memiliki tanggung jawab bersama, dan sesuai dengan keahlian yang tenaga pendidik miliki. Makanya tanggung jawab kepala harus memahami betul semua psikologis bawahannya. Supaya tugas yang mereka kerjakan sesuai dengan keahliannya.

Kepala sekolah, guru, staf-staf dan pengawas lainnya harus mampu mengembangkan berbagai potensial disekolah sehingga mampu mencari dan mengembangkan dalam menemukan makna dari apa yang dilakukannya. Tugas Kepala sekolah menyusun Rencana Pengembangan Sekolah (RPS) yang baik, serta mampu memberikan keleluasan kebebasan dalam bergerak kepada siswa-siswa, tenaga kependidikan, dan para stafstaf lainnya dengan tujuan mencari, membangun, membentuk, mengaplikasikan, serta mengembangkan ilmu pengetahuan, dteknologi yang sesuai dengan perubahan globalisasi, dan perubahan zaman. kesuksesan sekolah sangat dipengaruhi oleh kompetensi yang dimiliki kepala sekolah, semakin tinggi kemampuan kepala sekolah dalam mengelola lembaga, maka semakin bermutu sekolah tersebut, maupun sebaliknya, semakin menurun kompetensi guru, semakin renda kualitas sekolah tersebut. Maka seorang kepala sekolah dalam menggerakan komponen-komponen yang ada disekolah ( who is behind the school). Kemampuan kepala sekolah tersebut yang sangat penting dan sangat berpengaruh terutama yang berkaitan dengan pengetahuan dan pemahamanyang mereka miliki, kepala sekolah harus mampu mengelola manajemen serta mempunya jiwa yang pimpinan, sertabertanggung jawab terhadap tugas yang dibebankan kepadanya (Mulyasa ;2012).

Setiap perubahan dalam sistem pendidikan tujuanya sama, yaitu kearah dalam meningkatkan mutu dan kualitas pendidikan, jika perubahan dalam system pendidikan yang salah satu indikatornya adalah memberikan dampak positif yang dapat terjadi meningkatnya semangat, prestasi belajar peserta didik. Disini Pengaruh guru dalam perbaikan semangat belajar siswa, atau peningkatan prestasi belajar siswa sangat besar, bias dikatakan guru merupakan peran utama dalam mempengaruhi siswa, jika dibandingkan dengan pengaruh sekolah. Hal ini sesuai dengan penelitian yang dilakukan Nye, Konstantopoulus, dan Hedges yang memberikan kesimpulan bahwa pengaruh tenaga pendidik kepada prestasi belajar siswa adalah nyata, karena tenaga pendidik betemu langsung dengan pendidik. 
Sejalan dengan dengan penelitian sebelumnya yang pernah mereka lakukan (Jamil Suprihatiningrum ; 2015).

Seiring dalam Undang-Undang No 14 Tahun 2005 tentang Guru dan Dosen yang dijelaskan dalam pasal 1 yang dengan menyatakan bahwa : tenaga pendidik adalah tenaga pendidik yang profesional dengan tugas utama mendidik siswa, mengajar siswa, membimbing siswa, mengarahkan siswa, melatih siswa, menilai siswa, serta mengevaluasi siswa pada pendidikan usia dini wajib belajar dua belas tahun dengan mengikuti jalur pendidikan formal, pendidikan dasar, pendidikan menengah, maupun pendidikan menengah atas.

Dalam mencapai tujuan pendidikan yang diharapkan, maka sangat dibutuhkan organisasi yang didalamnya terdapat organization cooperation atau kerja sama organisasi yang memerlukan manajemen yang matang agar pencapaian tujuan akan lebih efektif dan efisien. Dengan kata lain sesuai antara rencana dan realisasi, dan tidak terjadi penyelewengan dan kesenjangan dalam mengaplikasikan.

MAN 3 Sleman Yogyakarta atau disebut (MAYOGA) terletak di jalan Magelang Kilometer 4, berada di Desa Rogoyudan, Kelurahan Sinduadi, Kecamatan Mliati, Kabupaten Sleman, Daerah Istimewa Yogyakarta. MAN 3 Sleman merupakan sekolah Madrasah unggulan dan boarding scholl yang berkarakter combine school. Tujuan dari sistem pendidikan Madrasah Aliyah Negeri adalah berupaya menghasilkan manusia yang selalu beriman dan bertaqwa kepada Allah SWT.. Berbudi luhur, berkepribadian baik, mandiri, tangguh, cerdas dan berwawasan luas, kreatif, terampil dalam bercakap, berdisiplin tinggi, beretos kerja tinggi, profesional dalam melaksanakan tugas sebagai peserta didik, bertanggung jawab terhadap apa yang diperbuat, produktif, sehat jasmani dan rohani, memiliki semangat kebangsaan, cinta tanah air, mempunyai jiwa yang social, kesadaran akan sejarah bangsa dan sikap menghargai para pahlawan yang telah gugur, serta berorientasi pada masa depan yang baik (Hasil Dari Dokumentasi Profil MAN 3 Sleman Yogyakarta).

MAN 3 Sleman menfasilitasi siswa menggunakan kurikulum 2013, yakni dengan penambahan jam pelajaran. Prestasi-prestasi yang telah banyak dicapai oleh siswa, semua hal ini tidak terlepas dari peran kepala sekolah dan perang guru. Kepala sekolah dan tenaga pendidik telah berhasil dalam upaya mengantarkan siswanya pada prestasi yang setiap tahun semakin meningkat. Prestasi yang diraih adalah juara 1 KSM kimia tingkat nasional tahun 2017, juara 1 opsi bidang sains tingkat nasional, juara 1 OSN fisika tingkat nasional tahun 2017, juara 1 POSPENAS tingkat nasional 
tahun 2017, juara 1 lomba olimpiade matematika tingkat nasional tahun 2013. Dan masih banyak lagi prestasi-prestasi lainnya, baik dibidang akademik, maupun no-akademik. Sedangkan prestasi di non-akademik adalah juara 2 band religi tingkat nasional pada tahun 2013, juara 1 tari saman tingkat provinsi pada tahun 2016, bahkan peningkatannya signifikan, yaitu $268 \%$ dibandingkan dengan tahun sebelumnya. Mengembangkan keterampilan-keterampilan siswa lewat peran tenaga pendidik lainnya, sehingga menjadikan siswa yang berkualitas dalam bidang akademik maupun non-akademik.

Selain prestasi dalam bidang akademik, maupun non-akademik, siswa MAN 3 Sleman Yogyakarta banyak yang diterima di Perguruan Tinggi Negeri (PTN) dan juga Perguruan Tinggi Swasta (PTS), bahkan peningkatan ini setiap tahun meningkat, jika dibandingkan dengan tahun lalu. Prestasiprestasi yang telah diraih, tidak terlepas dari manajemen dan kerja keras program kepala sekolah MAN 3 Sleman untuk memajukan siswa-siswa yang berprestasi, termasuk dalam peningkatan profesionalitas guru dalam mengembangkan prestasi siswa, baik akademik maupun non-akademik ( Hasil Dari Dokumentasi Profil Sekolah MAN 3 Sleman Yogyakarta).

\section{Metode}

Penelitian ini termasuk kedalam penelitian lapangan yakni : penelitian yang dilaksanakan dilingkungan tertentu untuk melaksanakan pengamatan dan pengumpulan data yang dibutuhkan. Penelitian ini peneliti laksanakan di MAN 3 Sleman Yogyakarta. metode penelitian ini peneliti menggunakan penelitian kualitatif deskriptif. Ditinjau dari segi sifatnya, penelitian ini bersifat deskriptif, yaitu penelitian yang bertujuan menggambarkan secara lengkap, sistematis, dan akurat fakta serta karakteristik mengenai dalam bidang tertentu. Dalam hal ini berkaitan dengan manajemen kepala sekolah dalam peningkatkan profesionalitas guru Pendidikan Agama Islam di MAN 3 Sleman Yogyakarta. Dalam penulisan karya ilmiah ini peneliti tidak menipulasi atau memberikan perlakuan-perlakuan tertentu terhadap obyek penelitian, semua kegiatan atau peristiwa berjalan apa adanya. Subyek penelitian ini adalah kepala Sekolah MAN 3 Sleman Yogyakarta dengan melakukan beberapa metode yakni: observasi, wawancara, dan dokumentasi. Sedangkan Obyek penelitian yang akan dikaji dalam pelaksanaan penelitian manajemen kepala sekolah di MAN 3 Sleman Yogyakarta. dengan menganalisis dan menyajikan, dan menguraikan data, fakta secara sistematik tentang keadaan obyek sebenarnya. 


\section{Pembahasan}

Guru professional yaitu tenaga pendidik yang mampu memiliki kompetensi maupun kemampuan dalam mengembangkan dirinya menuju kearah yang bisa memberikan perubahan sehingga berdampak kepada apa yang mereka kehendaki. Dalam hal ini, peneliti dapat membagi Sedikitnya terdapat 2 kategori kompetensi yang mampu dimiliki oleh guru Pendidikan Agama Islam yakni, yang pertama kompetensi profesionalitas adalah keahlian yang dimiliki dalam merancang, mengembangkan tugas-tugas sebagai tenaga kependidikan, sehingga materi yang tenaga pendidik sampai kepada siswa yang mereka tuju, tenaga pendidik harus mempunya wawasan dalam melaksanakan tugas sebagai guru, yang meliputi penguasaan ilmu pengetahuan dan teknologi. Karena tantangan di zaman globalisasi sangat pesat, siswa-siswa dapat mencari informasi dalam media social, yang dapat memberikan tantangan kepada gurunya, maka seorang guru tidak hanya terpaut dengan ilmu yang mereka terapkan, melainkan menggali atau penguasaan ilmu pengetahuan secara mendalam, baik dalam pengasaan materi maupun dalam ilmu teknologi. Sedangkan yang kedua adalah kompetensi personal, yaitu meliputi terhadap guru yang harus pendidik miliki,yang pertama etika, yang kedua moral, yang ketiga pengabdian, yang keempat kemampuan social dan yang kelima memiliki spiritual yang tinggi dengan memberikan contoh-contoh teladan yang baik, taat beragama, serta mempunyai sifat social terhadap sesama, dengan alasan tidak memandang bentuk fisik, tubuh, maupun lingkungan setempat. Dari pemamaparan tersebut mengenai guru yang professional, hal ini banyak sedikitnya dimiliki dan memenuhi standarisasi yang dimiliki oleh guru MAN 3 Sleman Yogyakarta. Hasil yang telah dicapai ini tidak terlepas dari manajemen kepala sekolah dan kerja sama antara kependidikan dan staf-staf lainnya dalam meningkatkan profesionalisme guru, khsusnya guru Pendidikan Agama Islam di MAN 3 Sleman Yogyakarta. Kompetensi pertama dituntut para guru menguasai materi yang akan mereka ajarkan, dan perlu beberapa metode yang harus mereka terapkan kepada siswa. Sedangkan yang kedua seorang guru harus mempunyai kompetensi personal baik dalam lingkungan sekolah maupun diluar lingkungan sekolah, yakni memiliki hubungan baik antar guru dan masyarakat, serta meningkatkan spiritual dalam agama yang tinggi supaya dapat memberikan contoh yang baik kepada siswa.

Peran utama kepala sekolah ada tujuh, namun peneliti hanya akan membahasas peran kepala sekolah yang dimiliki atau yang sudah diterapkan oleh kepala sekolah di MAN 3 Sleman Yogyakarta, yang pertama 
sebagai edukator, yaitu tenaga pendidik, yang kedua sebagai manajer yaitu pemimpin yang memberikan solusi maupun perencanaan dalam lembaga, yang ketiga sebagai administrator yaitu yang bertugas mengurusi semua yang meliputi lembaga dan administrasi lainnya. Sedangkan yang ke empat kepala sekolah sebagai supervisor yaitu sebagai pengawas atau mengontrol tenaga kependidikan lainya, sehingga apa yang telah kepala sekolah planningkan sesuai antara rencana dan realisasi. Kalau terjadi penyelewengan dalam proses pelaksanaan kegiatan, kepala sekolah cepat mengambil langkah dalam perbaikan tersebut. Dalam pemaparan empat peran penting kepala sekolah tersebut, peneliti akan menguraikan secara ringkas bagaimana hubungan yang dimiliki oleh kepala sekolah dalam meningkatan kompetensi profesionalitas guru dalam mentransferkan pengetahuan kepada siswa.

Berdasarkan wawancara dengan bapak Nur Wahyudin Al Aziz selaku kepala sekolah MAN 3 Sleman Yogyakarta mengatakan bahwa:

\section{Educator}

Kepala sekolah MAN 3 Sleman Yogyakarta sebagai tenaga pendidik (educator), tugas kepala sekolah selalu memberikan peningkatkan atau perbaikan secara terus menerus mengenai kualitas baik secara sebagai pemimpin baik secara tenaga pendidik. Pembelajaran yang dilakukan oleh kepala sekolah maupun guru, berawal dari pengalaman yang mereka milikibaik secara pengalaman maupun materi.

Seorang kepala sekolah juga dituntut untuk menguasai materi meskipun tidak mengajarkan kepada siswanya. guru tidak hanya dituntut menguasai materi yang mereka ajarkan tapi sangat dituntut mempunyai pengalaman yang mumpuni, begitu juga seorang kepala sekolah, kepala sekolah harus mampu mengajar, dan menguasasi beberapa bidang, supaya para bawahan mengikuti dan menerapkan. karena faktor pengalaman sangat memberikan pengaruh sangat besar dalam peningkatan profesionalitas kepala sekolah, terutama dalam meningkatkan dan mendukung dalam terbentuknya pemahaman dan pengalaman tenaga kependidikan untuk dapat pelaksanaan tugasnya.

Pengalaman didapatkan kepala sekolah berawal dari semasa mereka menjadi seorang guru, kemudian meningkat menjadi (wakil) membantu kepala sekolah dalam mengurus administrasi, ditambah dengan anggota organisasi dalam kemasyarakatan, pengalaman ini sangat mempengaruhi kemampuan terhadap pengalaman kepala madrasah untuk mengembankan tugasnya sebagai pemimpin, serta mengikuti beberapa tranning dan yang pernah mereka ikuti. Kepala MAN 3 Sleman Yogyakarta sebelum sebelum 
diangkat sebagai kepala sekolah, sudah mempunyai berpengalaman dalam mengajar lebih kurang selama 20 tahun. Ini bukan jangka waktu yang singkat, dan dalam jangka waktu tersebut, kepala sekolah sudah dapat memperoleh prestasi-prestasi serta jabatan yang pernah dirainya. Salah satunya menjabat sebagai wakil kepala sekolah swasta, dan kepala sekolah negeri. Dan di masyarakat beliau juga termasuk aktivis dalam beroganisasi dalam kemasyrakatan.

\section{Manajer}

Kepala MAN 3 Sleman Yogyakarta telah melaksanakan tugas dan fungsinya sebagai manajer, beliau selalu melaksanakan, memahami serta mewujudkan dalam tindakan, perilaku, maupun perbuatan seperti nilainilai atau keterampilan yang terkandung didalam bukunya Wahjosumidjo mengenai manager (tahun 1999 halaman 101), mengatakan: yang pertama Technical skills, Technical skills merupakan keahlian khusus yang harus dimiliki dan tanggung jawab kepala sekolah untuk melaksanakan tugasnya sebagai pemimpin.

Kepala MAN 3 Sleman Yogyakarta mempergunakan, memanfaatkan, dan melengkapi sarana, peralatan yang kurang, karena sarana dan prasarana merupakan sangat penting untuk membantu dan mendukung dalam melaksanakan kegiatan, bagaimana suatu pekerjaan bias terselesaikan dengan baik, sedangkan sarana dan prasarana tidak lengkap, dan tidak dimanfaatkan dengan baik. Yang kedua Human skills, Human skills yaitu kepala sekolah dapat memahami masalah psikologis bawahannya, karakternya, dan pengetahuan yang mereka miliki, ini sangat berpengaruh besar terhadap proses pembelajaran, dengan tujuan untuk mewujudkan dan meningkatkan kualitas pembelajaran.

Selain itu kepala sekolah MAN 3 Sleman Yogyakarta harus mempunyai komunikasi yang sangat baik dengan para tenaga pendidik, mapun staf-staf lainnya, dengan tujuan agar menciptakan suasana yang kondusif, berkualitas, terjalin silaturrahmi, sehingga kepala sekolah dalam memberikan tugas kepada bawahanya senang dan semangat untuk melaksanakan tugas yang didapatkannya.

\section{Administrator}

Peran kepala sekolah MAN 3 Sleman Yogyakarta sebagai pengatur (administrator) untuk mewujudkan organisasi atau lembaga yang bermutu, seorang kepala sekolah harus mengembangkan dan mengatur tugas-tugas yang menjadi tanggung jawab bersama, pengaturan dari kepala sekolah tidak hanya menjadi tanggung jawab kepala sekolah, tapi menjadi tanggung 
jawab bersama. dalam mengurusi adminstarsi, hal ini dibantu oleh para staf bawahannya, yang meliputi dari wakil kepala sekolah, para staf, para guru dan ketenaga administrasi lainnya. Dalam berkemampuan manajerial kepala sekolah dapat diaplikasikan dan diwujudkan dalam bentuk melaksanaan tugas administrasi, dengan segala kegiatan atau tugas yang ada di sekolah, dalam perwujudan ini merupakan tanda-tanda dalam mengasah kemampuan kepala madrasah. Kemampuan kepala madrasah dalam hal ini juga memperlihatkan adanya peraturan dalam melaksanakan tugas, dengan harapan dapat memperlancar dan mempermudah tenaga pendidik, para staf dan bawahan, untuk mencapai program yang telah mereka rencanakan, sehingga sesuai dengan apa yang mereka harapkan, dengan kata lain, tidak terjadi penyelewengan dan kesenjangan antara rencana dan realisasi.

\section{Supervaisor}

Kepala sekolah MAN 3 Sleman Yogyakarta sebagai manajer. manajer merupakan pencerminan dari seorang kepemimpinan. Kepala sekolah sebagai pemimpin harus memiliki pengetahuan dan wawasan yang luas, serta tanggung jawab yang tinggi dalam mencapai atau meningkatkan total quality management sekolah. Untuk mencapai kualitas tersebut, kepala sekolah MAN 3 Sleman Yogyakarta memiliki tanggung jawab dan kewenangan dalam mengatur, menggerakkan, dan memberi pengawasan. Menciptakan suatu lembaga yang berkualitas.

Kepala MAN 3 Sleman Yogyakarta menjelaskan bahwa untuk mengatur, dan mengarahkan tidak semudah apa yang diharapkan, dan mempunyai manajemen yang matang dalam mencapai program kualitas terebut, ada lima pokok yang sangat penting dalam mencapai sekolah yang bermutu dan berkwalias, yang pertama manajemen kurikulum, yang kedua manajemen personalia, yang ketiga manajemen kesiswaan,, yang ke empat manajemen keuangan, dan yang kelima manajemen kesiswaan.

Namun dibawah ini peneliti hanya membahas beberapa manajemen untuk meningkatkan quality manajemen tersebut, yang pertama manajemen kurikulum, yang kedua manajemen personalia, dan yang ketiga manajmen kesiswaan. ketiga manajemen pokok tersebut, merupakan sangat penting dan sangat terkait mengenai peningkatan profesionalias guru di MAN 3 Sleman Yogyakarta khsusunya dalam bidang Pendidikan Agama Islam (PAI).

\section{Manajemen Kurikulum}

MAN 3 Sleman menfasilitasi siswanya dengan kurikulum 2013, yaitu dengan penambahan jam pembelajaran. Kurikulum 2013 merupakan 
pedoman dari pemerintah Menteri Kependidikan, secara simbolis pada umumnya MAN 3 Sleman Yogyakarta sudah merencanakan dan mengaplikasikan apa yang sudah di fatwakan oleh pemerintah.

Hal ini terlihat dalam system pembelajaran yang dilakukan, yaitu guruguru mengajar sesuai dengan kurikulum yang sudah diterapkan pemerintah, dan mengikuti standarisasi acuan tersebut, sehingga guru-guru yang mengajar mengikuti KTSP yang diberlakukan di MAN 3 sleman, meskipun proses belajar dan pembelajaran dilakukan di kelas, lapangan, maupun di laboraturium, tetapi tetap mengarah dengan standarisasi pemerintah.

Namun tanggung jawab kepala sekolah MAN 3 Sleman Yogyakarta, meskipun sudah ada panduan dalam system pembelajaran, kepala sekolah tetap meningkatkan bahkan mengembangkan, dan menambah kurikulum tersebut, demi perbaikan dan perubahan yang lebih baik. Seperti selalu melaksanakan pengajian rutin bulanan, hari raya kurban, ikut partispasi dalam masyarakat lingkungan setempat, serta pengajian-pengajian hari besar Islam.

\section{Manajemen Personalia}

Manajemen personalia merupakan sangat penting untuk Meningkatkan Sumber Daya Manusia (SDM). Apapun organisasi yang dilakukan tidak terlepas dari SDM dengan tujuan menciptakan dan mewujudkan lembaga yang kondusif, berkualias, dan bermutu. Kepala MAN 3 Sleman Yogyakarta mengatakan bahwa Dengan mempunyai Sumber Daya Manusia yang banyak serta berkualitas, dapat memberikan efek samping terhadap pengembangan lembaga tersebut, bagaimana suatu lembaga akan berkembang, tetapi tidak mempunyai SDM yang mumpuni.

Sumber Daya Manusia akan optimal jika dikelola dengan baik. Kepala sekolah MAN 3 Sleman Yogyakarta harus memiliki peran yang penting dan wawasan yang luas supaya dapat mengelola manajemen sekolah dengan baik. Kepala sekolah dengan wawasan yang luas akan sangat mudah untuk menerapkan dan memahami manajemen personalia untuk mengelola lembaga madrasah tersebut.

Oleh sebab itu kepala sekolah sangat dituntut untuk mengembangkan dan mempunyai strategi yang matang dalam mengelola manajemen personalia, dantaranya: kepala sekolah harus tau betul mana tenaga pendidik yang berkualitas dan tidak berkualitas. Kepala sekolah MAN 3 Sleman Yogyakarta Dalam penerimaan tenaga kependidikan, kepala sekolah menginformasikan kepada tenaga pendidik lain bahwa ada penambahan tenaga pendidik, setelah diadakan penerimaan, yang lulus akan di tes lagi 
oleh pihak seklah dengan berbagai tes, seperti wawancara, ujian tulis, dan wawasan keagamaan, meskipun akademik tinggi, tapi tidak mempunyai spiritual yang tinggi maka tidak akan diluluskan. Setelah calon guru baru diterima, akan dilaksanakan pelatihan selama 3 bulan, untuk meningkatkan kemampuan dalam penguasaan materi, dan menjelaskan peraturanperaturan yang ada di MAN 3 Sleman Yogyakarta.

\section{Manajemen Kesiswaan}

Sekolah yang bermutu dan berkualitas, bukan sekolah atau lembaga yang dapat mengatakan, melainkan masyarakat, siswa, dan lingkungan tersebut, karena sekolah yang bermutu, masyarakat akan mengukur dengan siswa-siswa, atau prestasi-prestasi yang mereka capai, baik prestasi, tingkat sekolah, kecamatan, kabupaten, provinsi, maupun Nasional. Hal ini akan terlihat dari out put yang dihasilkan. Bagaimana suatu lembaga dikatakan berkualitas kalau siswa-siswanya banyak yang tidak diterima di Perguruan Tinggi Negeri (PTN) maupun Perguruan Tinggi Swasta (PTS).

MAN 3 Sleman Yogyakarta, sudah diakui oleh Kemendibuk dan Kemendinas, bahwa MAN 3 Sleman suatu lembaga yang bermutu dan berkualitas, terlihat dari saat Kemendiknas menghadiri acara yang dilaksanakan oleh MAN 3 Sleman. Kemendiknas mengatakan bahwa siswasiswa MAN 3 Sleman banyak diterima diperguruan tinggi negeri dan perguruan tinggi swasta. Dengan mencapai 90\% yang lulus, kemudian prestasi-prestasi yang pernah diraih oleh siswa MAN 3 Sleman baik akademik maupun non-akademik, dari tinggkat sekolah, kecamatan, kabupaten, provinsi, maupun tingkat nasional. Seperti lomba biologi tingkat provinsi, lomba matematika tingkat provinsi, lomba mata pelajaran kimia tingkat nasional, dan masih banyak lagi prestasi yang diraihnya.

Prestasi-prestasi tersebut, tidak terlepas dari program kerja keras dari manajemen kepala sekolah, serta serja sama dengan guru yang mempunyai kedisiplinan yang tinggi dan berkemampuan yang tinggi. Itu merupakan kerja keras bersama dan saling melengkapi.

\section{Kesimpulan}

Berdasarkan dari pembahasan tersebut, data dan temuan yang peneliti uraikan, peneliti dapatkan dari hasil wawancara bersama bapak Nur Wahyudin Al Aziz selaku kepala sekolah MAN 3 Sleman Yogyakarta, serta dukungan dari dokumentasi yang sudah baku. Pembahasan dalam penelitian ini peneliti fokuskan kepada manajemen kepala sekolah dalam mengelola suatu lembaga madrasah untuk menciptakan sekolah yang berkualitas tinggi. Yaitu manajemen kepala sekolah dalam peningkatan 
profesionalitas guru Pendidikan Agama Islam (PAI) di MAN 3 Sleman Yogyakarta. Dapat peneliti ambil beberapa kesimpulan.

1. Kepala sekolah sangat berpengaruh terhadap profesionalitas guru, khususnya guru Pendidikan Agama Islam di MAN 3 Sleman Yogyakarta. Hal ini sudah dilakukan dengan baik demi terciptanya pembelajaran yang kondusif. Maka kepala sekolah harus meningkatkan dan memanajemen suatu organisasi dengan baik, agar tidak terjadi penyelewengan dan kesenjangan antara rencana dan realisasi. Sehingga tujuan dengan sangat mudah untuk dicapai.

2. Peningkatan profesionalisme guru PAI di MAN 3 Sleman Yogyakarta bekerja sama dengan staf-staf lainnya, dan tidak dapat dilakukan sendirinya. Hal ini butuh bantuan dan dukungan dari pihak lain, seperti masyarakat setempat, dan staf-staf lainya, dengan kata lain bekerja sama dengan pihak tertentu, supaya program yang dijalankan dapat tercapai secara efektif dan efesien. Manajemen Kepala sekolah dalam meningkatkan profesionalisme guru PAI di MAN 3 Sleman tidak terlepas dari kegiatan manajemen baik dalam bidang kurikulum, personalia, kesiswaan. MAN 3 Sleman Yogyakarta juga memiliki SDM yang sangat mumpuni dan mempunyai tenaga kependidikan sertifikasi untuk mencapai tujuan tersebut.

\section{Daftar Rujukan}

Abdul Choliq, Pengantar Manajemen , Semarang : Rafi Sarana Perkasa, 2011.

Bapak Nur Wahyudin Al Aziz.kepala sekolah MAN 3 Sleman Yogyakarta Wawancara pada tanggal 25 November 2019 pukul 13.20 wib.

Daryanto, Standar Kompetensi dan Penilaian Kinerja Guru Profesional, Yogyakarta : Gava Media, 2013.

Dokumentasi, Profil MAN 3 Sleman Yogyakarta, Websibe, pada tanggal 21 November 2019, pukul 13.43 Wib.

Eka Prihatin, Manajemen Peserta Didik, Bandung : ALFABETA, 2011.

Jamil Suprihatiningrum, Guru Profesional, Yogyakarta : Ar-Ruzza Media, 2016.

Kompri, Manajemen Sekolah Orientasi Kemandirian Kepala Sekolah, Yogyakarta : Pustaka Belajar, 2015.

Mulyasa, Manajemen Kepemimpinan Kepala Sekolah, Jakarta : PT Bumi Aksara, 2012.

Mulyasa, Manajemen Kepemimpinan Kepala Sekolah, Jakarta : PT Bumi Aksara, 2012. 
Indel

Nana Syaodih Sukmadinata, Metode Penelitian Pendidikan, Bandung: UPI \& UPT Remaja Rosda Karya, 2005. 